Cahiers $d u$ MONDE RUSSE

\section{Cahiers du monde russe}

Russie - Empire russe - Union soviétique et États indépendants

55/3-4 | 2014

Varia

\title{
Alexander Gogun, Stalinskie kommandos, Ukrainskie partizanskie formirovanija 1941-1944
}

\section{Sebastian Stopper}

\section{(2) OpenEdition}

\section{Journals}

Electronic version

URL: http://journals.openedition.org/monderusse/8072

DOI: $10.4000 /$ monderusse. 8072

ISSN: $1777-5388$

\section{Publisher}

Éditions de l'EHESS

\section{Printed version}

Date of publication: 1 July 2014

Number of pages: $416-419$

ISBN: 978-2-7132-2441-6

ISSN: $1252-6576$

\section{Electronic reference}

Sebastian Stopper, «Alexander Gogun, Stalinskie kommandos, Ukrainskie partizanskie formirovanija 1941-1944», Cahiers du monde russe [Online], 55/3-4 | 2014, Online since 13 April 2015, Connection on 24 September 2020. URL : http://journals.openedition.org/monderusse/8072 ; DOI : https://doi.org/ 10.4000 /monderusse. 8072

This text was automatically generated on 24 September 2020.

(c) École des hautes études en sciences sociales 


\title{
Alexander Gogun, Stalinskie kommandos, Ukrainskie partizanskie formirovanija 1941-1944
}

\author{
Sebastian Stopper
}

\section{REFERENCES}

Alexander GOGUN, Stalinskie kommandos, Ukrainskie partizanskie formirovanija 1941-1944, Moscou : ROSSPEN (2éd., rev. et aug.), 2012, 527 p.

1 The Ukrainian partisan movement did not see substantial historical research yet, as Alexander Gogun correctly points out in his 2012 published second Russian edition of his book on partisan warfare in the Ukraine ${ }^{1}$ during the Second World War. In Soviet times a sincere treatment of the problematic could not be delivered due to restricted access to archives within the USSR and ideological boundaries. Publications by German and American historians were not restrained by axioms, but because of a broader setting a detailled account of the partisan warfare in the Ukraine could not be given. Only recently some Ukrainian historians ${ }^{2}$ started to adress the "painful points" of the history of the "Great Patriotic War," but were unable to cover the whole range of open questions and could not give answers formulated on a substantial basis of sources drawn from different archives.

2 Gogun's book closes the gap. While Belarus and the partisan formations there are already well researched, now the Ukraine too is examined in detail. What makes the authors book different from publications like for example Kenneth Slepyan's work on Soviet partisans during the Second World War ${ }^{3}$ is the consultation of a vast diversity of sources in five languages, including German, Ukrainian and Polish. Where experts like Bogdan Musial seem to get lost in describing every minute detail of events, ${ }^{4}$ Gogun's 
book "Stalinskie kommandos" delivers conclusive generalisations and deductions, while each chapter's caption presents core thesises to the reader.

Gogun did not only use memoirs and published documents for his research, but also draws on sources archived in Germany, Ukraine, Poland and Russia. The fact, that in the Ukraine two powerful anti-Soviet movements also reported on incidents, adds another type of sources to the available German and Soviet documents.

4 The author covers practically all aspects of historical questions about the Ukrainian partisan units. Introducing the reader into the topic by clarifying the process of organisation, Gogun then outlines the history of partisan warfare during the years of occupation in a condensed form. The chapter about the main tasks of the partisan detachments includes not only military operations and diversion, but also investigates the partisans' activities in the fields of reconnaissance, propaganda and terrorism. The formations and their members are examined in detail, providing historians with an adequate assessment of the social background of the irregular fighters and their psychological constitution. Fortunately Gogun does not dodge uncomfortable questions and research areas, but instead openly adresses the common disciplinary shortcomings of the partisan units and the widespread inner conflicts.

The resulting investigation of the Ukrainian partisans constitutes a valuable contribution to the historiography of the Second World War. While the book has been written strictly according to scientific rules, owing to a journalistic style it stays highly readable. Being rich in detail it not only provides complementing information about omitted research areas but in fact convincingly corrects outdated distortions and persistent misinterpretations. Gogun has in some cases been accused of denouncing the Ukrainian partisan movement by selective usage of sources ${ }^{5}$, but this is definitely not the case. To the contrary, the abundance of evidence supports no other conclusion than labelling the described characteristics of the Ukrainian partisan formations as accurate and typical. On the other hand Gogun repeatedly succeeds in pointing out false accusations against the Soviet partisans that were even repeated in documents of the German invaders (p. 87, 185).

6 The Ukrainian partisan formations did not spring into existance spontanously due to rebellion of the people against Nazi rule, but instead these groups were organized by central Soviet governmental organs. The secret services of the Soviet Union played a major and decisive role in the permanent kindling of resistance and conflicts. Consequently Gogun decided to characterize these Red partisans not as "insurgents" but choses the indeed more adequate term of "commandos." Three groups can be distiguished, the small specialised squads of the secret service sent out with orders for diversion and terrorisation, military groups assigned with reconnaissance and the actual partisan saboteur detachments, that were composed of former Soviet soldiers left behind in the rear of the Wehrmacht, locals and Soviet officials.

7 The self-proclaimed "people's resistance" set themselves apart from those who they allegedly fought for and saw themselves as a military formation operating in the enemy 's rear.

8 Their ruthlessness became visible instantly, when from the first day they applied the tactics of "scorched earth." In the countryside for example this meant the destruction of agricultural economy, including even the attempt to destruct forests by fire. The 
cities of the occupied territory suffered too. The fate of the people living in the Ukraine was not taken into account.

Instead of erroneously interpreting the Soviet side as a mere object of events, what Soviet historians did when they presented the Soviet partisans as a reaction to the appearance of the German enemy (therefore the label "people's avengers"), Gogun describes the partisan as a structure with its own initial aims, tactics and strategies. Of course the author also stresses repeatedly the extreme savagery of the invaders (p. 17-21), also mentioning the Hungarian behaviour (p. 87, 123). According to the researcher, German readiness for cruelty that rooted in tradition in the 1940s was combined with the incredibly furious racism of national-socialism (p. 124). The Soviet saboteurs and terrorists perfectly understood this new quality and successfully used it to their own ends, deliberately provoking repressions of the aggressors against civilians.

10 Fighting the foreign German occupier of the Ukraine was a major assignment too, but rather difficult to accomplish. Open battle led to unbearable casualties, but petty diversion showed little effective results. Gogun points out, that the «Fascist » losses in manpower due to partisan acticity in fact were much lower than officially announced. Furthermore half of the death toll consisted of locals who fought the partisans in the ranks of the different units compiled by the German invaders. After the summer of 1942 the Ukrainian « commandos » seem to have concentrated more on sabotaging the railway system in the rear of the Wehrmacht. Although the partisans had every opportunity to do serious damage to the German war machine, the effects of their diversions remained negligible. They could not even provide the Soviet army with significant up-to-date reconnaissance. In order to cover up their inefficiency, they reported grossly exaggerated figures about their operations. Like all Soviet partisans, the Ukrainian partisans were not professionals. They were not less devoted to the Soviet system than their Belorussian or Russian brethren, loyalty towards the Soviet regime being the same for all Soviet partisans.

11 Terrorism was among the tasks of the Ukrainian partisans too. And not surprisingly the irregular activity of the Soviet commandos in the Ukraine always was accompanied by a significant level of terror. Murdering German prisoners of war was a common war crime endorsed by the Soviet command, but ultimate violence was also directed against anyone else who was identified as an "enemy." Nationalist "traitors" could not expect mercy.

12 The distinct style in which the Soviet partisans fought becomes especially obvious when the struggles in the Ukraine are compared to the other two irregulare formations acting there, the Ukrainian Insurgent Army and the Polish Home Army. The nationalist movement exercised ethnical terror and killed civilians in high numbers. The Soviet partisans in contrast showed some kind of distinct "class terror" which demanded less victims, according to the author. The Red partisans did not think in ethnical categories when it came to their mass terror and even went as far as annihilating whole Ukrainian villages, if those were located in Western Ukraine and under suspection to be "nationalist." In contrast, the Central and Eastern Ukraine did not experience these extreme acts of retaliations from Soviet partisans. But Soviet irregular strategy was far from protecting the people all the same.

13 The partisan formations were poorly supplied with provisions and mainly relied on requisitions to obtain food and clothing. In addition to this practice unthoughtful 
plunder or outright robbery was committed repeatedly by individual partisans. Moral as well as discipline were low. A multitude of sources reports pillaging, excessive drinking and rape. The Red partisans alienated the Ukrainian population, which lead to volunteers in the ranks of the formations being a minority. Most men had to be drafted forcefully. The inner relationship between the partisans of one unit was correspondingly strained. The rude atmosphere was characterized by distrust and fear, strict surveillance, subjection and brutal lawlessness.

While operating in the rear of the German Wehrmacht the different partisan formations did not cooperate as this might be expected, but instead very often rather clashed. Since the different "commandos" answered to different Soviet organisations, cooperation was not paramount. Instead competition arose which lead to inefficiency and other negative side-effects. But even commanders administrated by the same authorities often stood in conflict with each other. Furthermore there were disagreements with superiors about e.g. operational approaches.

These extreme phenomens of partisan warfare often are excused by simply stating "war is war," but Gogun rejects this kind of primitive evasion. He also negates, that the brutality of the irregular war in the occupied Ukrainian was kindled by the German methods of warfare and the Nazi occupational regime exclusively. Even the explanation of mutual escalation and radicalisation seems to be unsufficiant. Gogun instead identifies Stalin's distinct style of conducting irregular warfare as a major factor. A fighting militant Stalinism contributed crucially to trigger a merciless war of destruction in the Ukraine during the years of occupation 1941-1944.

\section{NOTES}

1. Alexander Gogun, Stalinskie kommandos: Ukrainskie partizanskie formirovanija. Maloizuchennye strnicy istorii. 1941-1944, M., 2008.

2. A. Kentij/V. Lozyc'kyj, Vijna bez poshchady i miloserdyja. Partizan'skyj rukh u tylu vermakhta v Ukraïni (1941-1944), Kyïv 2005.

3. Kenneth Slepyan, Stalin's Guerrillas : Soviet Partisans in World War II, University Press of Kansas, 2006.

4. Bogdan Musial, Sowjetische Partisanen : Mythos und Wirklichkeit, Paderborn 2009.

5. Aleksandr Mekhanik, Lozh, bolshaja lozh' i istoriia, Expert-Kazakhstan, 17.09.2014. http:// expertonline.kz/a886/ Anton Brinskiy, "Oksiumoron, ili kholop s uchenoi stepeniu," Svoimi imenami, Nº 19 (138), 07.05.2013. http://www.svoim.info/201319/?19_5_1 